\title{
PREVALENCE OF HYPERTENSION AND RELATED FACTORS AMONG OLDER PEOPLE IN NURSING HOME OF JEMBER, EAST JAVA, INDONESIA
}

\author{
Rismawan Adi Yunanto ${ }^{1 *}$, Tantut Susanto ${ }^{2}$, Hanny Rasni ${ }^{3}$, Latifa Aini Susmaningrum ${ }^{4}$, Kholid Rosyidi \\ Muhammad Nur ${ }^{5}$ \\ 1,2,3,4,5 Department of Community, Family, and Geriatric Nursing, Faculty of Nursing, University of Jember \\ *email: rismawanadi@unej.ac.id
}

\begin{tabular}{|c|c|}
\hline & $A B S T R A C T$ \\
\hline $\begin{array}{l}\text { Keywords: } \\
\text { activity daily living } \\
\text { blood pressure } \\
\text { depression } \\
\text { hypertension } \\
\text { older people } \\
\text { spirituality }\end{array}$ & $\begin{array}{l}\text { Older people (OP) have a high risk for hypertension related to changing during } \\
\text { older process in particularly system of cardiovascular. The purpose of this study is } \\
\text { to identify prevalence of hypertension and related factors among OP in nursing } \\
\text { home of Jember, East Java, Indonesia. A cross-sectional study was conducted among } \\
42 \text { of OP in nursing home. A self-administered questionnaire was used to identify } \\
\text { characteristic of participants. Data of activity daily living, cognitive function, emo- } \\
\text { tional status, depression status, and spiritual activity were measured using Katz } \\
\text { Index of Independence in Activities of Daily Living (ADL), Short Portable Mental } \\
\text { Status Questionnaire (SPMSQ), The Mini Mental State Examination (MMSE), De- } \\
\text { pression Anxiety Stress Scale } 14 \text { (DASS-14), and Daily Spiritual Experience Scale } \\
\text { (DSES), respectively. Blood pressure was measured using a standard protocol uti- } \\
\text { lizing a stethoscope and sphygmomanometer. A logistic regression analysis was } \\
\text { used to determine factors related to hypertension among OP. The mean of blood } \\
\text { pressure of systolic and diastolic among OP were } 131.90 \pm 16.56 \text { mmHg and } 82.02 \\
\pm 10.18 \text { mmHg, respectively. The prevalence of systolic and diastolic hypertension } \\
\text { among OP in nursing home were } 38.1 \% \text { and } 21.4 \% \text {, respectively. The factors of } \\
\text { systolic hypertension were age ( } p=0.038 \text { ), activity daily living (p=0.043), depres- } \\
\text { sion status ( } p=0.012 \text { ), and spiritual activity ( } p=0.015 \text { ). Meanwhile, factors of } \\
\text { diastolic hypertension were age ( } p=0.041 \text { ) and education ( } p=0.049 \text { ). Increasing } \\
\text { age of OP related to risk factor of hypertension with psychological problems like } \\
\text { depression. It could be reduced by existence of spiritual activity of OP. Provision of } \\
\text { health education on changes in the cardiovascular system and adaptation of lifestyle } \\
\text { changes in the OP will be able to reduce hypertension factors in the OP. }\end{array}$ \\
\hline
\end{tabular}

\section{ABSTRAK}

Kata Kunci:

aktivitas kegiatan hidup sehari-hari depresi hipertensi

lansia spiritual tekanan darah
Lansia memiliki risiko tinggi untuk menderita hipertensi akibat proses menua khususnya pada sistem kardiovaskular. Tujuan dari penelitian ini adalah untuk mengidentifikasi prevalensi hipertensi dan faktor-faktor terkait di antara lansia di Panti Sosial Lanjut Usia (PSLU) Jember, Jawa Timur, Indonesia. Studi cross-sectional dilakukan kepada 42 lansia PSLU Jember. Kuesioner data demografi digunakan untuk mengidentifikasi karakteristik peserta. Data aktivitas kehidupan sehari-hari, fungsi kognitif, status emosi, status depresi, dan aktivitas spiritual diukur menggunakan Katz Index of Independence in Activities of Daily Living (ADL), Short Portable Mental Status Questionnaire (SPMSQ), The Mini Mental State Examination (MMSE), Depression Anxiety Stress Scale 14 (DASS14), dan Daily Spiritual Experience Scale (DSES). Tekanan darah diukur dengan protokol standar menggunakan stetoskop dan sphygmomanometer. Analisis regresi logistik 
digunakan untuk menentukan faktor-faktor yang berhubungan dengan hipertensi pada lansia. Rata-rata tekanan darah sistolik dan diastolik adalah 131,90 $\pm 16,56 \mathrm{mmHg}$ dan $82,02 \pm 10,18 \mathrm{mmHg}$. Prevalensi hipertensi sistolik dan diastolik masing-masing adalah $38,1 \%$ dan $21,4 \%$. Faktor yang berpengaruh terhadap hipertensi sistolik adalah usia ( $\mathrm{p}=$ $0,038)$, aktivitas hidup sehari-hari $(\mathrm{p}=0,043)$, status depresi $(\mathrm{p}=0,012)$, dan aktivitas spiritual $(p=0,015)$. Sementara itu, faktor yang berpengaruh terhadap hipertensi diastolik adalah usia $(\mathrm{p}=0,041)$ dan pendidikan $(\mathrm{p}=0,049)$. Meningkatnya usia lansia terkait dengan faktor risiko hipertensi dengan masalah psikologis seperti depresi. Itu bisa dikurangi dengan adanya aktivitas spiritual dari lansia. Pemberian pendidikan kesehatan tentang perubahan dalam sistem kardiovaskular dan adaptasi perubahan gaya hidup lansia akan dapat mengurangi faktor hipertensi pada lansia.

\section{INTRODUCTION}

Hypertension is one of the main factors that have the most influence on Cardiovascular Disease(Wu et al., 2015). Hypertension is the main cause of $45 \%$ death of CVD. CVD is predicted to be the main cause of morbidity and mortality among OP worldwide by 2020 according to a WHO report that contributes on the high incidence of morbidity and mortality to older people (OP) with 9.4 million deaths worldwide per year. The adult population in Southeast Asia who have hypertension are 36\% (WHO, 2013). The prevalence of hypertension in Indonesia is $25.8 \%$. OP with hypertension in Indonesia is reported in the age group of 45-54 years amounted to $35.6 \%, 55-64$ years amounted $45.9 \%$, 65-74 years amounted $57.6 \%$, and over 75 years amounted $63.8 \%$ above (Badan Penelitian dan Pengembangan Kesehatan, 2013; Kementrian Kesehatan RI, 2014).

The aging process experienced by OP and an increase in the value of blood pressure (BP) in $\mathrm{OP}$ are major factor in the occurrence of hypertension in OP (Buford, 2017). Increased blood level in the OP is a normal condition, but maintaining blood pressure on the save level is very difficult (Santschi et al., 2017). Nursing homes are a place for the OP who do not have a family or for the OP who really want to live there. The prevalence of hypertension in nursing homes residents is a common case and they need special treatment from health care workers (Wei and Omar, 2017).

Previous study in Shanghai showed that hypertension among OP was related to various factors such as age, Body Mass Index (BMI), lower level education, diet pattern, alcohol and non - cormobidities (Yang et al., 2017). Another study in Delhi showed that strong factors that related to hypertensions are age, education, and also cholesterol levels (Kishore et al., 2016). With the identification of these factors, it is expected find another factors that is related to hypertension of OP in the nursing home. Therefore, the objective of the study was to investigate of hypertension and related factors among OP in nursing home of Jember, East Java, Indonesia.

\section{METHODS}

This was a cross sectional study was conducted 42 OP who lived in nursing home of Jember as sample. The consecutive sampling technique was used to recruit the participants. The inclusion criteria of the participants were: (1) age ? 55 years; (2) resident of nursing home of Jember; (3) having the ability to communicate verbally with the researcher and understand all of the questions; and (4) signing the consent form. We excluded OP with psychological and cognitive disorder.

We collected the characteristics of the participants, Katz Index of Independence in Activities of Daily Living (ADL), Short Portable Mental Status Questionnaire (SPMSQ), The Mini Mental State Examination (MMSE), Beck's Depression Scales (BDS), Daily Spiritual Experience Scale (DSES), and blood pressure.

The characteristics of the participants selected for this study are as follows: age (years), gender (male or female), ethnic (Jawa, Madura, or Mixed), Education (not attending school or school), working history (non-permanent or permanent ), and marital status (single, divorced, married).

The Index ranks adequacy of performance in the six functions of bathing, dressing, toileting, transferring, continence, and feeding. Clients are scored yes/no for independence in each of the six functions (Wallace, 2008).

SPMSQ ease of scoring, e.g., a 10-item questionnaire. Category 1 indicates intellectual function intact; category 2 indicates mild intellectual impairment; category 3 indicates moderate intellectual impairment; and category 4 indicates severe intellectual impairment (Pfeiffer, 1975). 
MMSE is an 11-question measure that focuses on five areas of cognitive function: orientation (maximum scores 10), registration (maximum scores 3 ), attention and calculation (maximum scores 5), recall (maximum scores 3), and language (maximum scores 9). The maximum score is 30 . A score of 23 or lower indicates cognitive impairment. Category 1 indicates severe mental damage; category 2 indicates mild mental damage; and category 3 indicates good mental status (Wallace, 1999).

BDS measured 21 items with each item having scores from 0 to 3 and maximum scores 0 to 63 . BDS was categorized into 4 with category 1 indicates normal (scores 1 to 10 ); category 2 indicates mild mood disturbance (score 11-16); category 3 indicates moderate depression (score 16-30); and category 4 indicates severe depression (31-40); and category 5 indicates extreme depression (scores over 40) (Shahid et al., 2011).

A 16-item self-report measures spiritual experience on a 4-point scale: Not Close at All, Somewhat Close, Very Close, As Close as Possible. In this study, DSES was categorized into three categories, including category 1 (low spirituality), category 2 (mild spirituality), and category 3 (good spirituality) (Underwood and Teresi, 2002).

To measure blood pressure, we used a standard protocol employing a stethoscope and sphygmomanometer. In this study, we controlled blood pressure by maintaining systolic blood pressure below 140 $\mathrm{mmHg}$ and diastolic blood pressure below $90 \mathrm{mmHg}$ (Currie and Delles, 2018). In this study, uncontrolled hypertension was defined as systolic blood pressure ?140 $\mathrm{mmHg}$ or diastolic blood pressure $? 90 \mathrm{mmHg}$ based on the mean value measured.

The study has been approved by the Ethical Committee Review Board of Indonesia of the Faculty of Dentistry, University of Jember (100/UN25.8/ KEPK/DL/2018)

All research data were analysed using the IBM Statistical Package for Social Sciences software program, version 22.0. Statistic descriptive was used to determine the characteristics of the participants with mean and standard deviation (for numeric data) and percentage (for categorical data). Chi-square tests and t-tests of independence were used to compare categorical and continuous variables in systolic and diastolic blood pressure respectively. Furthermore, to determine factors related to systolic and diastolic blood pressure, a logistic regression analysis was used to examine the relationship between several factors of elders and hypertension of elders. A p-value $<0.05$ was considered statistically significant.

\section{RESULTS}

The prevalence of systolic and diastolic hypertension among OP who lived in nursing home of Jember were $38.09 \%$ and $21.43 \%$ respectively (Table 1). The characteristics of the participants (Table 1) showed that the mean age of the elders was $74.21 \pm$ 11.14 year with $50.00 \%$ male. Most of them were $(90.50 \%)$ were Javanese; $59.50 \%$ of the elders were educated; $73.80 \%$ of the elders were non-permanent worker, and $52.40 \%$ were maried. The health status of the elders was presented in Table 1. The elders in Nursing Home Jember mostly independent (71.4\%) in their daily activity. $54.80 \%$ of the elders had mild intellectual function in their cognitive function, while $76.20 \%$ of the elders had mild mental status. The elders mostly had moderate depression $(71.40 \%)$ and $81.00 \%$ of the elders had good spirituality activities. The mean of blood pressure of systolic was $131.90 \pm$ 16.56 and blood pressure of diastolic was $82.02 \pm$ 10.18. Table 1 also showed that there was a correlation between Depression and systolic hypertension $(p=0.013)$. Meanwhile, there was a correlation between age and diastolic hypertension $(p=0.036)$.

Table 2 showed that factors influenced systolic and diastolic hypertension among elders using logistic regression. Age $(p=0.038)$, activity $(p=0.043)$, depression $(\mathrm{p}=0.012)$, and spiritual $(\mathrm{p}=0.015)$ were significant factors of systolic hypertension. Meanwhile, age $(\mathrm{p}=0.041)$ and education $(\mathrm{p}=0.049)$ were significant factors of diastolic hypertension of the elders.

\section{DISCUSSION}

\section{Prevalence of Systolic Hypertension and Dyastolic Hypertension among Older People in Nursing Home of Jember}

The prevalence of systolic and diastolic hypertension among OP who lived in nursing home of Jember were $38.09 \%$ and $21.43 \%$. OP who lived as residents in nursing home of Jember have higher prevalence of hypertension due to limited health service management. Nursing home of Jember has less health worker that could provide health service to residents of nursing home. The sufficient number of health worker in nursing home will provide a quality health services to OP (Zainol and Pettit, 2016). Previous research also suggesting that living in nursing home for OP can contribute to various health problem due to lack of health service management. However, nursing home as an institution based management program could enhance the health status of OP 
Table 1. Correlation between Sociodemographic and Elderly Health Status with Hypertension Systolic-Diastolic

\begin{tabular}{|c|c|c|c|c|c|c|c|c|}
\hline \multirow[t]{2}{*}{ Variable } & & \multirow[t]{2}{*}{ Total } & \multicolumn{3}{|c|}{ Hypertension Systolic } & \multicolumn{3}{|c|}{ Hypertension Diastolic } \\
\hline & & & Normal & Hypertension & $\begin{array}{c}p- \\
\text { value }\end{array}$ & Normal & Hypertension & $\begin{array}{c}p- \\
\text { value }\end{array}$ \\
\hline \multicolumn{9}{|l|}{ Age } \\
\hline & & $74.21 \pm 11.14$ & $73.62 \pm 12.72$ & $75.19 \pm 8.23$ & 0.663 & $72.85 \pm 11.87$ & $79.22 \pm 6.06$ & $0.036^{\dagger}$ \\
\hline \multicolumn{9}{|l|}{ Gender } \\
\hline & Male & $21(50.0)$ & $15(57.7)$ & $6(37.5)$ & 0.340 & $14(42.4)$ & $7(77.8)$ & 0.133 \\
\hline & Female & $21(50.0)$ & $11(42.3)$ & $10(62.5)$ & & $19(57.6)$ & $2(22.2)$ & \\
\hline \multicolumn{9}{|l|}{ Ethnic } \\
\hline & Madura & $4(9.5)$ & $3(11.5)$ & $1(6.5)$ & 0.979 & $4(12.1)$ & 0 & 0.647 \\
\hline & Jawa & $38(90.5)$ & $23(88.5)$ & $15(93.8)$ & & $29(87.9)$ & $9(100)$ & \\
\hline \multicolumn{9}{|l|}{ Education } \\
\hline & $\begin{array}{l}\text { Not attending } \\
\text { school }\end{array}$ & $17(40.5)$ & $10(38.5)$ & $7(43.8)$ & 0.988 & $11(33.3)$ & $6(66.7)$ & 0.155 \\
\hline & School & $25(59.5)$ & $16(61.5)$ & $9(56.3)$ & & $22(66.7)$ & $3(33.3)$ & \\
\hline \multicolumn{9}{|c|}{ Working history } \\
\hline & Non-permanent & $31(73.8)$ & $20(76.9)$ & $11(68.8)$ & 0.823 & $25(75.8)$ & $6(66.7)$ & 0.903 \\
\hline & Permanent & $11(26.2)$ & $6(23.1)$ & $5(31.3)$ & & $8(24.2)$ & $3(33.3)$ & \\
\hline \multicolumn{9}{|c|}{ Marital status } \\
\hline & Single & $3(7.1)$ & $1(3.8)$ & $2(12.5)$ & 0.258 & $3(9.1)$ & 0 & 0.449 \\
\hline & Divorce & $17(40.5)$ & $9(34.6)$ & $8(50.0)$ & & $12(36.4)$ & $5(55.6)$ & \\
\hline & Married & $22(52.4)$ & $16(61.5)$ & $6(37.5)$ & & $18(54.5)$ & $4(44.4)$ & \\
\hline \multicolumn{9}{|l|}{ KATZ } \\
\hline & Independent & $30(71.4)$ & $\begin{array}{l}10(38.5) \\
16(61.5)\end{array}$ & $14(87.5)$ & $0.14 J$ & $23(69.7)$ & $7(77.8)$ & \\
\hline \multicolumn{9}{|l|}{ SPMSQ } \\
\hline & Moderate & $7(16.7)$ & $6(23.1)$ & $1(6.3)$ & 0.299 & $7(21.2)$ & 0 & 0.204 \\
\hline & Mild & $23(54.8)$ & $14(53.8)$ & $9(56.3)$ & & $16(48.5)$ & $7(77.8)$ & \\
\hline & Good & $12(28.6)$ & $6(23.1)$ & $6(37.5)$ & & $10(30.3)$ & $2(22.2)$ & \\
\hline MIIVISL & $\mathrm{Bad}$ & $5(11.9)$ & $3(11.5)$ & $2(12.5)$ & 0.674 & $5(15.2)$ & 0 & 0.167 \\
\hline & Mild & $32(76.2)$ & $19(73.1)$ & $13(81.3)$ & & $23(69.7)$ & $9(100)$ & \\
\hline & Good & $5(11.9)$ & $4(15.4)$ & $1(6.3)$ & & $5(15.2)$ & 0 & \\
\hline \multicolumn{9}{|c|}{ Depression } \\
\hline & Moderate & $30(71.4)$ & $21(80.8)$ & $9(56.3)$ & $0.013^{\dagger \dagger}$ & $22(66.7)$ & $8(88.9)$ & 0.391 \\
\hline & Mild & $9(21.4)$ & $2(7.7)$ & $7(43.8)$ & & $8(24.2)$ & $1(11.1)$ & \\
\hline & No depression & $3(7.1)$ & $3(11.5)$ & 0 & & $3(9.1)$ & 0 & \\
\hline spiritual & Mild & $8(19.0)$ & $7(26.9)$ & $1(6.3)$ & 0.210 & $6(18.2)$ & $2(22.2)$ & 1.000 \\
\hline & Good & $34(81.0)$ & $19(73.1)$ & $15(93.8)$ & & $27(81.8)$ & $7(77.8)$ & \\
\hline
\end{tabular}

Note: $\dagger$ Determined using t-independent test; $\dagger \dagger$ Determined using Chi square.

Blood pressure of systolic $($ Mean $\pm \mathrm{SD})=131.90 \pm 16.56 \mathrm{mmHg}$

Blood pressure of diastolic $($ Mean $\pm \mathrm{SD})=82.02 \pm 10.18 \mathrm{mmHg}$

Category blood pressure of systolic $=$

Hypertension $=16(38.1 \%)$

Normal $=26(61.9 \%)$

Category blood pressure of diastolic $=$

Hypertension $=9(21.4 \%)$

Normal $=33(78.6 \%)$

with health promotion (Sombateyotha et al., 2016). Therefore, the management of health services in nursing homes needs to be improved by increasing the number of health workers, coaching of health workers, or getting special training for health workers so that hypertension problems in the elderly can be managed properly.

\section{Factors Related to Hypertension}

This study showed that age and education 
Table 2. Logistic Regression Factors Influenced Hypertension Systolic-Diastolic Among Elderly

\begin{tabular}{|c|c|c|c|c|c|c|c|c|c|}
\hline \multirow{3}{*}{ Variable } & & \multicolumn{4}{|c|}{ Hypertension Systolic } & \multicolumn{4}{|c|}{ Hypertension Diastolic } \\
\hline & & \multirow[t]{2}{*}{ OR } & \multirow[t]{2}{*}{$\begin{array}{c}p- \\
\text { value }\end{array}$} & \multicolumn{2}{|c|}{$95 \% \mathrm{CI}$} & \multirow[t]{2}{*}{ OR } & \multirow[t]{2}{*}{$\begin{array}{c}p- \\
\text { value }\end{array}$} & \multicolumn{2}{|c|}{$95 \% \mathrm{CI}$} \\
\hline & & & & Lower & Upper & & & Lower & Upper \\
\hline Age & & 1.114 & 0.038 & 1.006 & 1.233 & 1.090 & 0.041 & 1.185 & 1.199 \\
\hline \multirow[t]{3}{*}{ Gender } & & $\mathrm{N} / \mathrm{A}$ & - & - & - & & & & \\
\hline & Male & - & - & - & - & 0.130 & 0.053 & 0.016 & 1.024 \\
\hline & Female & - & - & - & - & Ref & - & - & - \\
\hline \multirow[t]{3}{*}{ Education } & & N/A & & & & & & & \\
\hline & Not attending schools & - & - & - & - & 0.151 & 0.049 & 0.023 & 0.988 \\
\hline & Attending schools & - & - & - & - & Ref & - & - & - \\
\hline \multirow[t]{3}{*}{ Katz } & & & & & & $\mathrm{N} / \mathrm{A}$ & - & - & - \\
\hline & Dependent & 33.535 & 0.043 & 1.121 & 1003.374 & - & - & - & - \\
\hline & Independent & Ref & - & - & - & - & - & - & - \\
\hline \multirow[t]{4}{*}{ SPMSQ } & & & & & & $\mathrm{N} / \mathrm{A}$ & & & \\
\hline & Moderate & 0.366 & 0.688 & 0.003 & 49.066 & - & - & - & - \\
\hline & Mild & 14.480 & 0.296 & 0.097 & 2167.145 & - & - & - & - \\
\hline & Good & Ref & - & - & - & & & & \\
\hline \multirow[t]{4}{*}{ MMSE } & & & & & & $\mathrm{N} / \mathrm{A}$ & & & \\
\hline & Moderate & 0.057 & 0.103 & 0.002 & 49.066 & - & - & - & - \\
\hline & Mild & 0.064 & 0.229 & 0.097 & 2167.145 & - & - & - & - \\
\hline & Good & Ref & - & - & - & - & - & - & - \\
\hline \multirow[t]{4}{*}{$\begin{array}{l}\text { Depressio } \\
\mathrm{n}\end{array}$} & & & & & & $\mathrm{N} / \mathrm{A}$ & & & \\
\hline & Moderate & 43.605 & 0.012 & 2.321 & 819.27 & - & - & - & - \\
\hline & Mild & 0.000 & 0.999 & 0.000 & . & - & - & - & - \\
\hline & No depression & Ref & - & - & - & - & - & - & - \\
\hline \multicolumn{10}{|l|}{ Spiritual } \\
\hline & Mild & 167.547 & 0.015 & 2.756 & 10186.08 & $\mathrm{~N} / \mathrm{A}$ & & & \\
\hline & Good & Ref & - & - & - & - & - & - & - \\
\hline
\end{tabular}

Note: $\mathrm{OR}=$ Odds ratio; $\mathrm{CI}=$ Confidence interval; $\mathrm{N} / \mathrm{A}=$ Not applicable for analysis models; Ref $=$ References number. Significance finding in bold.

Hypertension systolic $=-2 L_{L x}^{2}=28.571(p=.001)$; Hosmer and Lemeshow test $\left(x^{2}\right)=5.118(p=0.745)$; Cox and Snell R2 $=0.477$; Nagelkerke R2 $=0.649$.

Hypertension systolic $=-2 L_{L x}{ }^{2}=53.793(p=.001)$; Hosmer and Lemeshow test $\left(x^{2}\right)=9.618(p=0.293)$; Cox and Snell R2 $=0.047$; Nagelkerke R2 $=0.06$

were found to be an important risk factors for hypertension. Similar findings were reported that age and education can be a risk factor for hypertension (Bansal et al., 2012; Kishore et al., 2016; Singh, Shankar and Singh, 2017). Aging process will cause the blood vessels to be stiffened and no longer elastic, so this contributes on the prevalence of hypertension to OP (Buford, 2017). Education plays an important role in maintain health against disease influenced by lifestyle. The level of education is an important factor of someone to be able to understand a new information and apply it in the process of overcoming the health problems. Previous research has proved that level of education is an influential factor on gaining some infor- mation and further influences health-seeking behavior among older in developing countries (Irwan et al., 2016). These results suggest that education has a great influence for OP on understanding their health status. Structured health education for nursing home residents is an alternative for the OP to improve their ability in controlling blood pressure.

Our finding showed that depression is an important factor on hypertension in OP in nursing home. Similar findings also showed by previous research which was stated that depression was one of factors related to hypertension in OP who lived in nursing home (Facp et al., 2013; Chang and Lee, 2015; Neupane et al., 2015; Stanetic et al., 2017). Of 
interest, one study explained that depression in OP could increase cortisol that associated altered sympathetic activity in OP with the metabolic syndrome and also high blood pressure (Bacon et al., 2014). Therefore, it is necessary to have psychosocial management in the nursing home of Jember to formed a group therapy for decreasing hypertension problems of the OP.

Our finding showed that activity daily living (ADL) is correlated to hypertension. Similar findings also showed by another research that stated daily activity of the OP was an important risk factor of hypertension (Warren-Findlow, Seymour and Huber, 2012; Zainol and Pettit, 2016; Twinamasiko et al., 2018). Previous research suggesting that the workstyle of people is one of factor that related to hypertension (Sohn et al., 2015). Another study indicates that people with an active workstyle had lower blood pressures compared to people with non-active workstyle (Twinamasiko et al., 2018). This may be explained by the existence of the level of independence of OP in performing basic daily activities, which will impact on the ability of the OP to maintain the health problems issues (Mollao?lu, Solmaz and Mollao?lu, 2015). The results of this study suggest that the elders still maintain the functional status of independence in fulfillment of basic needs. So, the elders can establish self-efficacy to control blood pressure.

This current study also showed that spirituality is correlated to hypertension among OP in nursing home of Jember. This result is consistent with previous research suggesting that spirituality has an important role in controlling blood pressure. Spirituality has a positive influence on increasing the resilience of OP with hypertension, thus, improving their blood pressure (Silva et al., 2016). The process of praying can increase calmness that lead to a greater feelings of gratitude. The impact of this process is the decrease of cortisol that one of major problem of hypertension (Javanmard, 2012). Previous study also stated that spiritual activity that could be done by OP can decrease the level of stress and cortisol hormone, so the OP can control the blood pressure (Supriyadi, Sugijana and Dwiningsih, 2017). Hence, it is worth that spirituality is an important factor on hypertension in OP in nursing home of Jember.

Based on those findings, health-promotion programs on the management of the health behavior of OP based on the characteristics of institution-based rehabilitation has a very important role in modifying factors of hypertension among OP (Susanto et al., 2019). Health promotion programs such as health education about hypertension in nursing homes will provide benefits in improving self-management of OP in dealing with hypertension problems (Wei and Omar, 2017). Another study also suggested that an institution-based health management program improved the knowledge, per-ceived self-efficacy, received social sup-port, health promotion behaviors, and health status of older people in nursing home (Sombateyotha et al., 2016).

\section{LIMITATION}

This study has limitations regarding the measured prevalence of OP with hypertension and the related factors, which may be different from what has been identified in other studies, based on sample size and kind of management of health care in the nursing home of Jember. However, regarding this research, we suggest for maintaining health service management of nursing home of Jember to provide health services for OP with hypertension.

\section{CONCLUSION}

Increasing age of OP related a risk factor of hypertension by supported by there are psychological problems like depression, although could be reduced by existence of spiritual activity of OP. Provision of health education on changes in the cardiovascular system and adaptation of lifestyle changes in the OP will be able to reduce hypertension factors in the OP.

\section{ACKNOWLEDGMENTS}

The author would like to thank Faculty of Nursing and Department of Research and Community Engagement of University of Jember for funding of Research Group (Kelompok Riset/KeRis) Healthy and Wellness of Elderly Studies (HWES) and Internship students of They would also like to thank the intership students from the subject of Gerontic Nursing for collecting the data, who practiced in Elderly Rehabilitation of Jember.

\section{REFERENCES}

Bacon, S. L. et al. (2014) 'The Impact of Mood and Anxiety Disorders on Incident Hypertension at One Year', 2014.

Bansal, S. K. et al. (2012) 'The prevalence of hypertension and hypertension risk factors in a rural Indian community: A prospec- 
tive door-to-door study', Journal of Cardiovascular Disease Research, 3(2), pp. 117-123. doi: 10.4103/0975-3583.95365.

Buford, T. W. (2017) 'HHS Public Access', pp. 96111. doi: $10.1016 /$ j.arr.2016.01.007.Hypertension.

Chang, A. K. and Lee, E. J. (2015) 'Factors affecting self-care in elderly patients with hypertension in Korea', International Journal of Nursing Practice, 21(5), pp. 584591. doi: 10.1111/ijn.12271.

Currie, G. and Delles, C. (2018) 'Blood pressure targets in the elderly', Journal of Hypertension, 36(2), pp. 234-236. doi: 10.1097/ HJH.0000000000001576.

Facp, A. F. R. et al. (2013) 'Depression increases the risk for uncontrolled hypertension', 18(1), pp. 10-12.

Irwan, A. M. et al. (2016) 'Self-care practices and health-seeking behavior among older persons in a developing country: Theories-based research', International Journal of Nursing Sciences. Elsevier Ltd, 3(1), pp. 11-23. doi: 10.1016/ j.ijnss.2016.02.010.

Javanmard, H. (2012) 'The impact of spirituality on work performance', Indian Journal of Science and Technology, 5(1), pp. 19611966. doi: $10.17795 / \mathrm{semj} 39053$.

Kementrian Kesehatan RI (2014) 'Pusat Data Informasi Kementrian Kesehatan RI Hipertensi', Health Education \& Behavior, 2(4), pp. 328-335. doi: 10.1177/ 109019817400200403.

Kishore, J. et al. (2016) 'Prevalence of Hypertension and Determination of Its Risk Factors in Rural Delhi', International Journal of Hypertension, 2016. doi: 10.1155/2016/ 7962595.

Mollao?lu, Mukadder, Solmaz, G. and Mollao?lu, Muratcan (2015) 'Adherence To Therapy and Quality of Life in Hypertensive Patients.', Acta clinica Croatica, 54(4), pp. 438-44. Available at: http:// www.ncbi.nlm.nih.gov/pubmed/ 27017717.

Neupane, D. et al. (2015) 'Prevalence of Undiagnosed Depression among Persons with Hypertension and Associated Risk Factors?: A Cross-Sectional Study in Urban Nepal', pp. 1-11. doi: 10.1371/ journal.pone.0117329.

Pfeiffer, E. (1975) 'A short portable mental status questionnaire for the assessment of organic brain deficit in elderl y patients', Journal of American Geriatrics Society., (23), pp. 433-41.

Santschi, V. et al. (2017) 'Team-based care for improving hypertension management among outpatients (TBC-HTA): Study protocol for a pragmatic randomized controlled trial', BMC Cardiovascular Disorders. BMC Cardiovascular Disorders, 17(1), pp. 1-6. doi: 10.1186/s12872017-0472-y.

Shahid, A. et al. (2011) 'Beck Depression Inventory', STOP, THAT and One Hundred Other Sleep Scales, pp. 63-64. doi: 10.1007/ 978-1-4419-9893-4_8.

Silva, C. D. F. et al. (2016) 'Spirituality and religiosity in patients with systemic arterial hypertension Research articles', 24(2), pp. 332-343.

Singh, S., Shankar, R. and Singh, G. P. (2017) 'Prevalence and Associated Risk Factors of Hypertension: A Cross-Sectional Study in Urban Varanasi', International Journal of Hypertension. Hindawi, 2017. doi: $10.1155 / 2017 / 5491838$.

Sohn, M.-W. et al. (2015) 'Sedentary Behavior and Blood Pressure Control', 22(9), pp. 1234-1240. doi: 10.1016/ j.joca.2014.07.007.SEDENTARY.

Sombateyotha, K. et al. (2016) 'Effect of institutionbased management for elderly health promotion program in northeastern Thailand', Southeast Asian Journal of Tropical Medicine and Public Health, 47(5), pp. 1062-1088.

Stanetic, K. et al. (2017) 'Prevalence of depression in patients with hypertension *1', 3(2), pp. 16-21.

Supriyadi, Sugijana, R. and Dwiningsih, S. U. (2017) 'Religious Therapy as an Alternative Treatment in Reducing the Cortisol Hormone and Blood Sugar', ARC Journal of Public Health and Community Medicine, 2(3), pp. 1-6. doi: 10.20431/24560596.0203001 .

Susanto, T. et al. (2019) 'Prevalence of hypertension and predictive factors of self-efficacy among elderly people with hypertension in institutional-based rehabilitation in Indonesia', Kontakt. Kontakt, 21(1), pp. 14-21. doi: 10.32725/kont.2018.007.

Twinamasiko, B. et al. (2018) 'Sedentary Lifestyle 
and Hypertension in a Periurban Area of Mbarara, South Western Uganda?: A Population Based Cross Sectional Survey'. Hindawi, 2018. doi: 10.1155/ 2018/8253948.

Underwood, L. G. and Teresi, J. A. (2002) 'The daily spiritual experience scale: Development, theoretical description, reliability, ...', Annals of Behavioral Medicine, (13), pp. 22-33. Available at: http:// www.springerlink.com/index/ L177J557V44K1874.pdf\%5Cnpapers:/ / d c 652 f 93 - 0 df $4-43$ a 0 - a d a 0 2f05f429e241/Paper/p129.

Wallace, B. M. (2008) 'Katz Index of Independence in Activities of Daily Living ( ADL ) Katz Index of Independence in Activities of Daily Living INDEPENDENCE?: DEPENDENCE?':, Ajn, 108(2), pp. 67-71. doi: 10.1016/S01974572(00)70015-2.

Wallace, M. (1999) 'The Mini Mental State Examination ( MMSE) The Mini-Mental State Exam', European radiology, (3), pp. 7780. doi: january, 1999.

Warren-Findlow, J., Seymour, R. B. and Huber, L. R. B. (2012) 'The association between self-efficacy and hypertension self-care activities among African American adults', Journal of Community Health, 37(1), pp. 15-24. doi: 10.1007/s10900011-9410-6.

Wei, T. M. and Omar, M. S. (2017) 'Self-management approaches among hypertensive residents in nursing homes in Malaysia.', Malaysian family physician?: the official journal of the Academy of Family Physicians of Malaysia, 12(3), pp. 8-17. Available at: http:// www.ncbi.nlm.nih.gov/pubmed/ $29527274 \% 0 \mathrm{Ahttp}: / /$ www.pubmedcentral.nih.gov/ articlerender.fcgi?artid=PMC5842418.

WHO (2013) 'World Health Day 2013 - Hypertension', A global brief on hypertension, $\mathrm{p}$. 9. doi: 10.1136/bmj.1.4815.882-a.

$\mathrm{Wu}, \mathrm{L}$. et al. (2015) 'Trends in prevalence, awareness, treatment and control of hypertension during 2001-2010 in an Urban elderly population of China', PLoS ONE, 10(8), pp. 1-14. doi: 10.1371/ journal.pone.0132814.

Yang, Z. Q. et al. (2017) 'Prevalence and control of hypertension among a Community of Elderly Population in Changning District of Shanghai: A cross-sectional study', BMC Geriatrics. BMC Geriatrics, 17(1), pp. 1-9. doi: 10.1186/s12877-017-0686y.

Zainol, R. and Pettit, C. J. (2016) 'Elderly and Community Health Care Facilities: a Spatial Analysis', Planning Malaysia Journal, 14(5). doi: pmjournal.v14.i5.192.
$10.21837 /$ 